\title{
Practical guidance for clinical laboratories for SARS-CoV-2 serology testing
}

\author{
Carmen Charlton 1,2,3*, Jamil Kanji1,2,4, Vanessa Tran ${ }^{5,6}$, Julianne Kus ${ }^{5,6}$, Jonathan Gubbay, \\ Carla Osiowy ${ }^{7}$, Jason Robinson 8 , Inna Sekirov ${ }^{9}$, Michael Drebot ${ }^{7}$, Todd Hatchette ${ }^{10}$, Derek Stein ${ }^{11,12}$, \\ Nadia El-Gabalawy ${ }^{7}$, Amanda Lang ${ }^{13}$, Lei Jiao ${ }^{10}$, Paul Levettt ${ }^{11}$, Heidi Wood ${ }^{7}$, Christian Therrien ${ }^{14}$, \\ L Robbin Lindsay ${ }^{7}$, Muhammad Morshed ${ }^{9}$, Jessica Forbes ${ }^{6}$, Antonia Dibernardo ${ }^{7}$ on behalf of the \\ Canadian Public Health Laboratory Network (CPHLN) Serology Working Group
}

\section{Abstract}

The landscape of severe acute respiratory syndrome coronavirus 2 (SARS-CoV-2) diagnostic testing is rapidly evolving. While serology testing has limited diagnostic capacity for acute infection, its role in providing population-based information on positivity rates and informing evidence-based decision making for public health recommendations is increasing. With the global availability of vaccines, there is increasing pressure on clinical laboratories to provide antibody screening and result interpretation for vaccinated and non-vaccinated individuals. Here we present the most up-to-date data on SARS-CoV-2 antibody timelines, including the longevity of antibodies, and the production and detection of neutralizing antibodies. Additionally, we provide practical guidance for clinical microbiology laboratories to both verify commercial serology assays and choose appropriate testing algorithms for their local populations.

Suggested citation: Charlton CL, Kanji JN, Tran V, Kus JV, Gubbay J, Osiowy C, Robinson JL, Sekirov I, Drebot M, Hatchette T, Stein DR, El-Gabalawy N, Lang A, Jiao L, Levett PN, Wood H, Therrien C, Lindsay LR, Morshed M, Forbes JD, Dibernardo A on behalf of the Canadian Public Health Laboratory Network (CPHLN) Serology Working Group. Practical guidance for clinical laboratories for SARS-CoV-2 serology testing. Can Commun Dis Rep 2021;47(4):171-83. https://doi.org/10.14745/ccdr.v47i04a01

Keywords: COVID-19, SARS-CoV-2, serological testing, serology algorithms

\section{Introduction}

The emergence of severe acute respiratory syndrome coronavirus 2 (SARS-CoV-2) in December 2019 resulted in a rapid global development of molecular, antigenic and serological assays for the diagnosis of acute infection and identification of past infection. While molecular testing is widely accepted as the gold standard for diagnosis of acute infection, the role of serology is limited to special clinical cases as an adjunct for diagnosis (1). The SARS-CoV-2 antibodies are not reliably detected fewer than 7-21 days post symptom onset, making their utility in diagnosis of acute infection of limited value (2-4). However, in cases such as multiple inflammatory syndrome in adults (MIS-A) or in children (MIS-C), a positive result on a serological assay can help guide clinical management in the absence of a positive molecular test result or when molecular testing is unavailable, and positive serology results have been included as part of the clinical case definition for MIS-C (5). Outside these very specific clinical scenarios, the role of serology assays is to examine population-based prevalence rates of SARS-CoV-2, and to help inform public health decisions.

To improve the utility of serology testing, an international standard is required to allow direct comparison of assays between laboratories. Population-based studies linking quantitative serology results to clinical outcomes will be needed to help determine what level of antibody may correlate with immunity to infection. Such approaches would be similar to what has been done with other viruses (e.g. rubella), where an international standard is used to calibrate assays and a quantitative serological immunoglobulin $\mathrm{G}(\mathrm{lgG})$ is used to determine immunity (more than $10 \mathrm{lU} / \mathrm{ml}$ ), or
This work is licensed under a Creative Commons Attribution 4.0 International License.

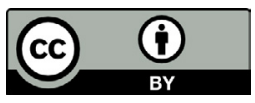

Affiliations

1 Public Health Laboratory, Alberta Precision Laboratories, Edmonton, AB

2 Department of Laboratory Medicine and Pathology, University of Alberta, Edmonton, $\mathrm{AB}$

${ }^{3}$ Li Ka Shing Institute of Virology, Edmonton, $A B$

${ }^{4}$ Division of Infectious Diseases, Department of Medicine, University of Alberta, Edmonton, AB

${ }^{5}$ Public Health Ontario Laboratory, Toronto, ON

${ }^{6}$ Department of Laboratory Medicine \& Pathobiology, University of Toronto, Toronto, ON

${ }^{7}$ National Microbiology Laboratory, Public Health Agency of Canada, Winnipeg, MB

${ }^{8}$ Provincial Laboratory Services, Division of Clinical Chemistry, Health PEl, Charlottetown, PE

${ }^{9}$ British Columbia Centre for Disease Control Public Health Laboratory, Vancouver, BC

${ }^{10}$ Newfoundland and Labrador Public Health Microbiology Laboratory, St. John's, NL

${ }^{11}$ Department of Medical Microbiology and Infectious Disease, University of Manitoba, Winnipeg, MB

${ }^{12}$ Cadham Provincial Laboratory, Winnipeg, MB

${ }^{13}$ Roy Romanow Provincial Laboratory, Regina, SK

${ }^{14}$ Laboratoire de santé publique du Québec, Institut national de santé publique du Québec, Sainte-Anne-deBellevue, QC

\section{*Correspondence:}

carmen.charlton@

albertaprecisionlabs.ca 
susceptibility (less than $10 \mathrm{lU} / \mathrm{ml}$ ) to infection, based on correlation with clinical outcomes $(6,7)$. Multiple quantitative serological assays have been submitted to accreditation agencies globally, including the Food and Drug Administration (FDA), Health Canada and European Council (Conseil européen); however, to date in North America, there remains a gap in approved quantitative assays that have a correlation with immunity from infection (i.e. neutralizing antibodies). While this will not impact clinical decision making on an individual level, this remains a critical gap in the interpretation and utility of SARS-CoV-2 serology testing for serosurveillance studies.

Here we examine the current knowledge of serological testing, discuss assay limitations, describe how clinical laboratories can both validate these assays and implement appropriate algorithms for local patient populations, discuss the role for differentiating antibodies derived from natural infection versus those that are vaccine-derived and consider options for detection of neutralizing antibodies.

\section{Seroconversion timelines}

The antibody response to SARS-CoV-2 is relatively well studied; however, there is substantial variability in seroconversion timelines given the heterogeneity amongst populations studied (i.e. disease severity, age, presence of comorbidities, etc.), serologic tests used and serologic markers analyzed. In general, the overall range of seroconversion regardless of the type of antibody, is estimated to be between four and 14 days post-onset of symptoms $(2,8,9)$. An early study evaluated seroconversion rates in 173 patients and reported median seroconversion times for total antibody (Ab), immunoglobulin $M(\lg M)$, and $\lg G$ that were 11, 12 and 14 days, respectively. However, the authors reported that fewer than $40 \%$ of patients had detectable antibodies within one week of onset of illness and this rose to $100 \%$ (total $\mathrm{Ab}$ ), $94 \%$ (IgM) and $80 \%$ (lgG) by day 15 in the same patients (10). In contrast, another study reported the seroconversion rate of immunoglobulin $\mathrm{A}(\lg \mathrm{A})$ was similar to $\operatorname{lgM}$, with a median seroconversion of five days (IQR 3-6) after symptom onset compared with 14 days for $\operatorname{lgG}$ (11). Despite earlier detection of $\lg M$ in those studies, the time course for $\lg M$ and $\lg G$ seroconversion rates are similar for SARS-CoV-2 compared with other infectious diseases, where IgM preceded IgG by weeks. Indeed, both IgG and IgM detection signals were found to plateau six days after the first positive serology test among 285 coronavirus disease 2019 (COVID-19) patients (9). Thus, while studies agree that seroconversion occurs within 4-14 days of symptom onset and that lgG and IgM seroconversion dynamics are similar, the considerable variability leads to poor sensitivity of antibody testing for diagnosis of acute COVID-19, which has been well documented in the literature $(1,2,12)$.

\section{Antibody longevity}

The length of time that antibody responses persists, and possibly confer protection from reinfection, is pivotal to understanding SARS-CoV-2 infection dynamics (detailed timeline for antibody detection can be seen in (9)). Using sequential serum samples from 65 patients and 31 seropositive healthcare workers, Seow et al. (13) showed seroconversion of $\lg M, \lg G$ and $\lg A$ occurred in more than $95 \%$ of cases when sampled equal to or greater than eight days post-symptom onset. Neutralizing antibody kinetics were consistent with other acute viral infections (13), with an initial peak at 3-4 weeks (magnitude of peak dependent on disease severity) followed by declining neutralizing antibody titres. Interestingly, patients with a high peak infectivity dose maintained neutralizing antibody titres longer compared with patients with a lower peak infectivity dose (13). Neutralizing antibody decline occurred simultaneously with declines in IgG titres against SARS-CoV-2 spike (S) glycoprotein and receptor-binding domain (RBD), as well as $\lg M$ and $\lg A$ binding to $\mathrm{S}$ glycoprotein and RBD. In patients with mild to moderate disease, IgG antibody titres were found to be stable for up to five months, with a significant correlation between anti-spike binding titres and neutralization (14).

Additional studies using plaque reduction neutralization test (PRNT)/microneutralization assays in combination with anti-spike enzyme-linked immunosorbent assay (ELISA) procedures have further validated the findings of longitudinal neutralization antibody duration $(15,16)$. Previously observed declines in antibody titres during the first few months after infection is expected as short-lived plasma cells are depleted; however, when these are replaced by long lived antibody secreting cells, neutralizing antibodies will persist for several months in most individuals (17).

Interestingly, longitudinal antibody longevity studies in serum and saliva showed that IgM and IgA levels rapidly declined following peak levels (18), while IgG remained relatively stable in both biofluids (up to 105 days post symptom onset). Similarly, others found that $92.3 \%$ of patients $(\mathrm{N}=427)$ remained $\mathrm{lgG}$ positive 3-6 months post symptom onset (19). While most evidence suggests that $\lg \mathrm{M}$ and $\lg \mathrm{A}$ antibody levels drop significantly compared with IgG isotypes, in patients with a remote history of COVID-19, they appear to play a key role in the initial neutralizing antibody response. Serum IgA was shown to contribute to virus neutralization up to one month following symptom onset (20), while IgM was shown to neutralize SARS-CoV-2 in both pseudoviral particle and wild type virus assays (21).

Lessons on antibody longevity for SARS-CoV-2 may be learned by studying other human coronaviruses; a strategy that has been reviewed extensively elsewhere (22). A recent systematic review highlighted the kinetics, protection correlations and antibody association with disease severity among human coronaviruses. In general, antibody responses to other human coronaviruses, such as SARS-CoV, Middle Eastern respiratory syndrome coronavirus (MERS-CoV) and seasonal coronaviruses, are present for one year after infection; in some cases, antibodies may persist for longer (23). Moreover, other evidence suggests that serum antibody titres remained relatively high two years 
after SARS-CoV infection, and up to $55 \%$ of patients had detectable antibodies at three years post infection (24). However, no detectable anti-SARS-CoV antibodies were observed in patients six years post infection (25). Similarly, antibodies against MERS-CoV have been shown to persist for approximately three years (26), although the persistence of anti-MERS-CoV antibodies depended on disease severity, as patients with subclinical or mild disease had low or undetectable levels of antibodies two years after infection (27). In contrast, seroprevalence studies of human coronavirus (HCoV)-229E and HCoV-OC43 suggested that antibody titres wane significantly one year after infection (22). The persistence of anti-SARS-CoV-2 antibody response remains to be seen although given the association of the antibody signal and disease severity (13), it is likely that persistence of antibodies will correlate with disease severity.

\section{Impact of disease severity and age}

Given that many SARS-CoV-2 infections are subclinical or asymptomatic, it is critically import that the antibody response (including titres, seroconversion and time to seronegativity) in these patient populations be well understood. It is now widely recognized that titres of SARS-CoV-2 antibodies are positively associated with clinical severity of disease. Zhao et al., (10) first reported that a significantly higher titre of total antibody was independently associated with a worse clinical classification $(p=0.006)$ at 2 -weeks post illness onset. A high total antibody titre was hypothesized to be a risk factor for critical illness and that it may even be used as a surrogate marker for worse clinical prognosis. A similar observation was made in 289 COVID-19 patients clinically categorized as having mild, moderate or severe infection. Patients with a severe infection had significantly higher levels of S1-specific lgA and IgG compared with those with a mild infection (28). Moreover, S1-specific lgG was detectable after two weeks in only $20 \%$ of patients in the mild group compared with $100 \%$ of patients in the severe and moderate groups.

The impact of disease severity on seroconversion kinetics and their relationship to neutralizing properties in serum is not well understood. When compared to patients with mild symptoms, those with severe symptoms had a significantly faster time to IgG seroconversion (median 22 versus 11 days, respectively) with approximately $10 \%$ of patients with mild symptoms never seroconverting (29). Detectable lgG levels were still observed more than 75 days post symptom onset in patients who had seroconverted. Interestingly, even at 90 days post-symptom onset a small number $(\mathrm{N}=3)$ of patients developed total antibody levels below the limit of detection of commercial assays yet still had a detectable neutralizing response (titre range of 8-48). This observation is in direct contrast to that reported previously, where sera from $20 \%$ of discharged patients had no neutralizing properties despite sera from $100 \%$ of patients showing seroconversion (30). Furthermore, in a small study, the development of IgM in patients with severe disease was delayed ( $N=6$; eight days) compared with mild disease ( $\mathrm{N}=39$; six days) (31). Jiang et al. (32) evaluated rates of seroconversion in non-severely ill patients with COVID-19, as well as asymptomatic patients, concluding that different lgM/lgG kinetics exist depending on the severity of the disease. Indeed, the authors reported that $\lg \mathrm{G}$ seroconversion occurred among $94 \%$ of symptomatic and $85 \%$ of asymptomatic patients while IgM seroconversion occurred in $74 \%$ of symptomatic patients and only $31 \%$ of asymptomatic patients $(p<0.001)$. Interestingly, the authors also reported that the median time to seroconversion (lgM or lgG) among the asymptomatic group was significantly shorter compared with the symptomatic group (median seven days from first positive polymerase chain reaction assay vs. 14 days; $p<0.001)$.

While it is generally accepted that antibodies persist for longer periods in severe cases of COVID-19, there is considerable variation among studies even when normalized for the clinical severity. For example, lgG in mild to moderate disease appears to persist anywhere from 3-5 months $(14,33)$. A study evaluating symptomatic and asymptomatic patients with COVID-19 associated pneumonia (apparent or subtle on radiography) found antibodies were more frequently detected among symptomatic patients ( $100 \%$ vs. $71 \%$; measured at two and five months post symptom onset) (34). Furthermore, titres decreased significantly between the two time points. Another study comparing IgG and neutralizing antibody levels in asymptomatic versus symptomatic patients showed $40 \%$ of the asymptomatic patients became seronegative in the early convalescent phase (2-3 months post symptom onset) compared with only $12.9 \%$ of symptomatic patients (35). Interestingly, Choe et al. (36) also reported that neutralizing antibody titre correlated with severity of disease, suggesting that patients with severe disease may be more protected from reinfection compared with patients with subclinical or asymptomatic infection. It should be noted that to date, there are only a few documented cases of reinfection (37-40), which suggests that either other immune mechanisms (such as the T cell-mediated response) may contribute to protection against SARS-CoV-2 reinfection, or that, as a function of the short time that SARS-CoV-2 has been circulating and combined with implementation of public health restrictions, sufficient time has not yet passed for re-infection to be detected. Additionally, as most of these early studies examined the level of anti-nucleocapsid antibodies, association of high levels of antibody with poorer clinical outcome may be related to the production of anti-nucleocapsid rather than anti-spike antibodies.

Although there are less data on the relationship between age and the antibody response in COVID-19, recent evidence suggests there may be distinct antibody responses in children and adults. It has been shown that unlike adults, who produced robust levels of anti-S and anti-nucleocapsid (N) antibodies, children produced less anti- $\mathrm{N}$ and neutralizing antibodies (41). 
The clinical significance of this is unknown, although it is interesting considering disease severity is positively associated with age.

The large variability in how the antibody response was measured (i.e. different assays, platforms, methods, and antigenic targets) makes it difficult to make direct comparisons between studies. Despite this limitation, it is clear that not all infected individuals will mount an antibody response and that the level of antibodies may wane over time. This has significant implications for the interpretation of antibody testing for diagnostic purposes, especially for use as a surrogate marker of immunity to SARS-CoV-2. At best, anti-SARS-CoV-2 antibodies have good positive predictive agreement for neutralizing properties; however, the negative predictive agreement is poor.

\section{How to implement testing in the clinical laboratory}

Validation of antibody tests for infectious disease often depends on studies aimed to calculate the diagnostic sensitivity and specificity (i.e. correlating assay response to true positives and true negatives). In the case of SARS-CoV-2, this is inherently difficult for several reasons. Evidence suggests that humoral response and resultant seropositivity are affected by the severity of infection (presence/absence of detectable antibody), the time since symptom onset (antibody longevity) and the antigen target (antibody isotypes and viral protein recognition). Moreover, because the sensitivity of ribonucleic acid (RNA) testing is dependent on the time of sample collection in disease and the quality of sample, discordant serology results are often difficult to interpret for most clinical laboratories that do not have access to neutralization assays. Therefore, it is recommended that clinical laboratories offer assays that have undergone extensive review by a governing body such as Health Canada or the FDA, or by published peer-reviewed performance analyses when available. The requirement is on the clinical laboratory to ensure serology assays are used as intended and meet local accreditation standards.

The complexity and scope of internal verification studies required for laboratories to offer serology testing is highly dependent on the method of choice. Many clinical laboratories will choose to offer automated chemiluminescent immunoassay methods using existing instrumentation and infrastructure that are Health Canada or FDA emergency use authorization approved. When using these validated methodologies, with provided performance characteristics, a modified method verification may be acceptable with reduced rigour of testing to ensure the assay is fit for purpose. However, modifications to a validated method, such as using a different specimen type like a dried blood spot or altering the manufacturer's cut-off, requires complete method validation prior to patient testing (considerations for verification and validation are shown in Table 1). In the case of a laboratory developed test, a complete method validation is required. A detailed flow diagram depicting additional possible scenarios for method validation and verification was published previously (42).

Table 1: Minimal requirements for validation and verification of qualitative assays

\begin{tabular}{|c|c|c|}
\hline Item & Verification & Validation \\
\hline Requirements & $\begin{array}{l}\text { Assay methodology and reagents must be unchanged from } \\
\text { the manufacturer's instructions }\end{array}$ & $\begin{array}{l}\text { Assay performance and methodology must be assessed and } \\
\text { determined in the local testing population }\end{array}$ \\
\hline Purpose & $\begin{array}{l}\text { Laboratory verifies that the operators using their assay } \\
\text { platform in their laboratory environment obtain the same } \\
\text { performance characteristics with the assay method as } \\
\text { described in the manufacturer's validation data }\end{array}$ & $\begin{array}{l}\text { Laboratory validates all performance characteristics in their } \\
\text { laboratory and all sample types to be used }\end{array}$ \\
\hline Sample number & $\begin{array}{l}\text { A statistically significant number of samples (generally } 50 \\
\text { minimum) must be used in the evaluation process to cover } \\
\text { the full range of expected results for the intended use }\end{array}$ & $\begin{array}{l}\text { A statistically significant number of samples (generally } 50 \\
\text { positive and } 50 \text { negative run over } 5-10 \text { days) must be used, and } \\
\text { cover the full range of expected results }\end{array}$ \\
\hline $\begin{array}{l}\text { Statistical } \\
\text { analyses }\end{array}$ & $\begin{array}{l}\text { A statistical correlation with existing validated methods or } \\
\text { comparisons with known outcomes ("gold standard") are } \\
\text { required for qualitative methods. \% CV, SD and } 95 \% \mathrm{Cl} \text { are } \\
\text { recommended }\end{array}$ & $\begin{array}{l}\text { A statistical correlation with existing validated methods or } \\
\text { comparisons with known outcomes ("gold standard") are } \\
\text { required for qualitative methods. \% CV, SD and 95\% Cl are } \\
\text { recommended }\end{array}$ \\
\hline Calculations & $\begin{array}{l}\text { Confirmation of Clinical Evaluation is the minimum to be } \\
\text { tested } \\
\text { Sensitivity/specificity: Minimum of } 20 \text { samples ( } 10 \text { positive, } \\
10 \text { negative), or a recommended } 100 \text { samples: } 50 \text { samples } \\
\text { valid for the method that are positive for SARS-CoV-2 RNA } \\
\text { and } 50 \text { negative samples valid for the method that are } \\
\text { negative for SARS-CoV-2 RNA OR that have been tested } \\
\text { by a validated comparator immunoassay and were positive } \\
(\mathrm{N}=50) \text { or negative }(N=50) \text { for SARS-CoV-2 antibody. Apply } \\
\text { the binary classification test ("Test outcome vs. condition") } \\
\text { to determine both characteristics. Determine Cl\%. }\end{array}$ & $\begin{array}{l}\text { All performance characteristics must be tested } \\
\text { Sensitivity/specificity: Recommended } 100 \text { samples: } 50 \\
\text { samples valid for the method that are positive for SARS-CoV-2 } \\
\text { RNA and } 50 \text { negative samples valid for the method that are } \\
\text { negative for SARS-CoV-2 RNA OR that have been tested by a } \\
\text { validated comparator immunoassay and were positive }(\mathrm{N}=50) \\
\text { or negative ( } \mathrm{N}=50) \text { for SARS-CoV- } 2 \text { antibody. Apply the binary } \\
\text { classification test ("Test outcome vs. condition") to determine } \\
\text { both characteristics. Determine Cl\%. }\end{array}$ \\
\hline
\end{tabular}


Table 1: Minimal requirements for validation and verification of qualitative assays (continued)

\begin{tabular}{|c|c|c|}
\hline Item & Verification & Validation \\
\hline $\begin{array}{l}\text { Calculations } \\
\text { (continued) }\end{array}$ & $\begin{array}{l}\text { Precision: is defined as the closeness of agreement between } \\
\text { independent test results obtained under conditions of } \\
\text { the assay run (includes repeatability and reproducibility). } \\
\text { Minimum of } 20 \text { samples: } 10 \text { replicates each of one positive } \\
\text { and one negative sample; } 10 \text { RNA positive and } 10 \text { RNA } \\
\text { negative samples. Create aliquots and freeze all aliquots } \\
\text { necessary for testing to avoid freeze-thaw variability } \\
\text { between repeats. If comparing to another immunoassay, a } \\
\text { range of S/CO values within the samples would be desirable. } \\
\text { Repeatability: Assay } 10 \text { replicates of the positive and } \\
\text { negative samples in a single run. Determine the SD and \% } \\
\text { CV for the S/CO values. } \\
\text { Reproducibility: Assay the } 20 \text { specimen aliquots on three } \\
\text { different days. Determine the SD and \% CV for the S/CO } \\
\text { values for each specimen. }\end{array}$ & $\begin{array}{l}\text { Diagnostic (clinical) sensitivity is defined as the percentage of } \\
\text { individuals with the target condition (as determined by the } \\
\text { diagnostic accuracy criteria) whose test values are positive. } \\
\text { Diagnostic (clinical) specificity is defined by the percentage of } \\
\text { individuals without the target condition (as determined by the } \\
\text { diagnostic accuracy criteria) whose test values are negative. } \\
\text { Target specificity (cross-reactivity) ensures the test is specific } \\
\text { only for the analyte of interest. This is determined by testing } \\
\text { other pathogens within the same family or disease group. } \\
\text { Positive predictive value is defined as the percentage of } \\
\text { individuals with a positive test result who have the target } \\
\text { condition (as determined by the diagnostic accuracy criteria). } \\
\text { Consider evaluating parameters as a function of the population } \\
\text { prevalence. } \\
\text { Negative predictive value is defined as the percentage of } \\
\text { subjects with a negative test result who do not have the target } \\
\text { condition (as determined by the diagnostic accuracy criteria). } \\
\text { Consider evaluating parameters as a function of the population } \\
\text { prevalence. } \\
\text { Precision: Create aliquots and freeze all aliquots necessary } \\
\text { for testing to avoid freeze-thaw variability between repeats. If } \\
\text { comparing to another immunoassay, a range of S/CO values } \\
\text { within the samples would be desirable. } \\
\text { Repeatability: Assay } 10 \text { replicates of the positive and } \\
\text { negative samples in a single run. Determine the SD and \% CV } \\
\text { for the S/CO values. } \\
\text { Reproducibility: Assay the } 20 \text { specimen aliquots on } 3 \text { different } \\
\text { days. Determine the SD and \% CV for the S/CO values for each } \\
\text { specimen. } \\
\text { Normal values: } 120 \text { specimens should be run to establish } \\
\text { normal range of values for local testing population. }\end{array}$ \\
\hline $\begin{array}{l}\text { Other } \\
\text { considerations }\end{array}$ & $\begin{array}{l}\text { When possible, laboratories should consider using multiple } \\
\text { operators to perform verification, particularly when result } \\
\text { interpretation is required } \\
\text { If the assay documentation does not include a full validation } \\
\text { report or incomplete performance characteristics as } \\
\text { recognized by technical organizations, then a user laboratory } \\
\text { validation is required }\end{array}$ & $\begin{array}{l}\text { When possible, laboratories should consider using multiple } \\
\text { operators to perform validation, particularly when result } \\
\text { interpretation is required }\end{array}$ \\
\hline
\end{tabular}

Method verifications are likely to be the most common form of method evaluation performed by clinical laboratories at present. At minimum, clinical laboratories should verify manufacturer claims by assessing the diagnostic sensitivity and specificity, assay precision (reproducibility), cross-reactivity of non-SARS-CoV-2 antibodies and interfering substances (such as hemoglobin, lipids or biotin) commonly found in their patient population. A summary of the minimum suggested sample sizes for establishing diagnostic sensitivity and specificity are provided in Table 2 . The clinical laboratory must verify the assay performance using statistical correlations and comparisons based on manufacturer claims. Careful scrutiny is required in the case of discrepant results, and arbitrator testing can be performed by external laboratories performing the same methodology. If verification specimens are sourced locally, patient history may be considered to reconcile test performance and to further characterize the testing population (outpatient, hospitalized or intensive care unit, and timing of sample collections). Furthermore, it may be prudent to interrogate the signal obtained from the assay in expected positives that may be in the equivocal range because some patient antibody titres may have waned over time, and assay cut-offs were assigned with only limited samples. A particular challenge during verification is resolving suspected false positive serologic results given the variable disease prevalence (43). Potential approaches to resolve discrepancies include testing for another assay or target antigen, reviewing the clinical history of the patient case, including time since symptom onset and contact tracing, or reviewing prior SARS-CoV-2 RNA testing results. 
Table 2: Theoretical number of samples required for establishing diagnostic sensitivity and specificity estimates by error margin and confidence interval

\begin{tabular}{|l|r|r|r|r|r|r|}
\hline \multirow{2}{*}{$\begin{array}{c}\text { Estimated } \\
\text { sensitivity } \\
\text { or } \\
\text { specificity }\end{array}$} & \multicolumn{3}{|c|}{ Estimate with $2 \%$ error } & \multicolumn{3}{|c|}{ Estimate with 5\% error } \\
\cline { 2 - 7 } & $90 \%$ & $95 \%$ & $99 \%$ & $90 \%$ & $95 \%$ & $99 \%$ \\
\hline $90 \%$ & 610 & 864 & 1,493 & 98 & 138 & 239 \\
\hline $92 \%$ & 466 & 707 & 1,221 & 75 & 113 & 195 \\
\hline $94 \%$ & 382 & 542 & 935 & 61 & 87 & 150 \\
\hline $95 \%$ & 372 & 456 & 788 & 60 & 73 & 126 \\
\hline $96 \%$ & 260 & 369 & 637 & 42 & 59 & 102 \\
\hline $97 \%$ & 197 & 279 & 483 & 32 & 45 & 77 \\
\hline $98 \%$ & 133 & 188 & 325 & 21 & 30 & 52 \\
\hline $99 \%$ & 67 & 95 & 164 & 11 & 15 & 26 \\
\hline
\end{tabular}

\section{Consideration of orthogonal testing algorithms for severe acute respiratory syndrome coronavirus 2 serology}

In general, laboratories should strive to use serological assays with manufacturer-claimed sensitivity of greater than $95 \%$ and specificity of greater than $99.5 \%$ (1). Many of the SARS-CoV-2 specific antibody assays currently approved for use in North America meet these performance criteria when used alone (44-48). However, when testing is performed in low prevalence populations or in patients with a low pre-test probability of disease the positive predictive value or post-test odds will be unacceptably low despite excellent specificity. Therefore, laboratory professionals may adopt an orthogonal testing strategy to improve the specificity and positive predictive values of serologic test interpretation for SARS-CoV-2 (49-51). In orthogonal testing, samples that test positive or equivocal on an initial test are re-tested using a second test to confirm or refute the result (1). Orthogonal testing strategies have been recommended by public health authorities in North America in low prevalence populations $(1,52)$, and detailed protocols are available (53). Most of the orthogonal testing approaches for SARS-CoV-2 antibodies involve two independent tests, each with unique assay design characteristics such as antigen type (54-56) or assay formats (57). However, these approaches may have practical limitations in terms of implementation because the specific epitope targeted in each manufacturers assay is unknown or not provided (58). Improvements in sensitivity can also be accomplished in orthogonal testing approaches by reducing cut-off values for commercial high-throughput automated SARS-CoV-2 assays (59); however, alteration of manufacturer recommendations requires full validation of the new cut-off values prior to clinical use.

When users are considering either a single serological testing algorithm or a two-step (orthogonal) testing algorithm, they must consider the reason for testing, the intended use of the data generated and the expected prevalence of SARS-CoV-2 in the population of interest. For example, use of serology for special clinical case testing (e.g. in MIS-C cases) or in seroepidemiological studies, requires high assay sensitivity and high negative predictive value in early infection (more than two weeks) and late convalescence, respectively. Indeed, in these scenarios reporting true cases should be the priority; although false positives are not desirable, they can be tolerated more so than false negatives. For example, in seroepidemiological studies, a sensitive assay with a good positive predictive value is critical to identify true cases to provide robust population level estimates of seropositivity. In contrast, when screening potential convalescent plasma donors, the presence of SARS-CoV-2 antibody is critical (60), and a positive predictive value more than $99 \%$ should be required. Because high negative predictive value is less important in this scenario, orthogonal testing is recommended in both low and high population prevalence levels (56). These examples illustrate the need for careful consideration of orthogonal testing strategies that are tailored to the intended use of the serological data. As a result of these different scenarios, SARS-CoV-2 antibody testing strategies will vary based on site-specific requirements.

\section{Serological assays to determine severe acute respiratory syndrome coronavirus 2 antibody neutralization potency}

To better understand and characterize SARS-CoV-2 immunity after natural infection or vaccination, functional assays such as virus neutralizing tests are required. The previous/current gold standard methodologies to detect and quantify SARS-CoV-2 neutralizing antibodies have used cell-culture-based infection assays, which block viral entry into cells in vitro. These live-virus assays use wild type SARS-CoV-2 virus incubated with dilutions of a patient's sera or plasma. The mixture is then added to susceptible cells to determine if the sera inhibits or neutralizes the cytopathological effect or plaque reduction is observed. PRNT provide a means to quantitate neutralization titres associated with an individual's clinical specimen. However, live virus assays require biosafety level-3 containment, are labour-intensive and due to the biologic variation associated with these assays they can be difficult to standardize (61-63).

Neutralization assays that use pseudotyped viruses, such as the vesicular stomatitis virus or lentivirus-based systems that incorporate SARS-CoV-2 spike protein, can be used in biosafety level-2 laboratories (64). An example of a basic procedure for establishing a pseudotype assay using lentivirus particles involves transfecting a "packaging" cell line, such as HEK 293T cells, with a number of plasmids to produce safe, non-replicative viral particles expressing the spike protein. Transfected plasmids include a reporter-expressing plasmid, a plasmid encoding the SARS-CoV-2 spike and a number of plasmids encoding lentiviral proteins required for assembling viral particles. The transfected cells produce the pseudotype viruses, which can then be used 
to infect permissive cells expressing the SARS-CoV-2 receptor, angiotensin-converting enzyme 2 (ACE2), to measure a decrease in cytopathological effect, via the reporter signal, or by plaque reduction in the presence of patient serum.

Although pseudotype virus formats alleviate biosafety limitations, they have similar drawbacks to conventional PRNTs in that they are difficult to standardize across laboratories, and the assay characteristics may vary depending on culture conditions, virus strains and cell lines used. Furthermore, these cell-based assays require highly skilled personnel, are low throughput and have suboptimal turnaround times for clinical decision making. These drawbacks make implementation of pseudotype viral assays in the clinical laboratory impractical.

Recently, several ELISA-based surrogate neutralization assays that detect antibodies targeting the viral spike protein RBD have come to market (65-67). These more rapid assays are based on antibody-associated blockage of the interaction between the spike RBD and the ACE2 receptor. The procedure by Abe et al., (67) uses immobilized ACE2 and soluble biotinylated RBD (which exhibited increased sensitivity to other reagent configurations), and provides a direct comparison with conventional ELISAs (detecting antibodies that bind RBD) in a plate format.

A number of commercial assays using a similar ELISA-based platform have also become available (e.g. GenScript cPass, Cayman SARS-CoV-2 antibody ELISA) that indirectly and semi-quantitatively measure the neutralizing capability of SARS-CoV-2 antibodies. The GenScript surrogate virus neutralization test (sVNT) kit has been compared with conventional cell-based neutralization assays (68-70) and displayed good specificity, and comparable sensitivity to virus culture-based assays, but demonstrated somewhat reduced efficacy in identifying samples with a lower level of virus neutralization potency. This observation may be explained by the specific detection of antibodies targeting the RBD in the assay, as non-RBD neutralizing antibodies are not targeted in the sVNT assays. It should also be noted that unlike functional PRNT or cell-based assays, surrogates may detect non-neutralizing antibodies in some samples. However, the advantage of both commercial and non-commercial ELISA-based sVNT assays is the ease of use and the potential for automation and standardization. Moreover, with appropriate validations, these may be incorporated into conventional virus neutralizing testing algorithms and offer an important tool to assess neutralization in clinical specimens.

Additional standardization is underway to compare cell-based neutralization assays with surrogate tests utilizing pseudotype viruses or ELISA-based competitive binding assays (71). Good correlation was observed between a modified ELISA-based surrogate assay with a conventional PRNT and spike pseudotyped viral vector-based platforms (67). Antibody titres between TCID50 neutralization tests and lentiviral/vesicular stomatitis virus pseudotype assays correlated well (71). It should be noted that although cell-based neutralization assays, such as PRNTs or micro-neutralization tests, are the reference standards for detection and quantification of neutralizing antibodies in clinical specimens, the biological nature of these test may lead to some variability in titres and sensitivity when comparing inter-laboratory results (72). The utilization of proficiency panels made up of well pedigreed control and patient sera/plasma samples facilitates standardization between laboratories.

Commercially available, high-throughput serological assays that measure the binding of antibodies to various viral antigens have been directly compared to neutralization antibody titres in patient samples using PRNT or sVNT assays (73-75). The results from these comparisons show that commercial serology assays are sensitive for the detection of total antibodies but are less robust at predicting the neutralization titre relative to conventional (e.g. PRNT) or sVNT assays. Furthermore, the reliability of commercial high-throughput platforms that are specific for spike/RBD protein antigens to infer neutralization titre equivalents may depend upon time frames for specimen collection and the specific antibody induction responses of an individual. However, more recent studies have described a strong correlation between anti-RBD antibody concentrations and spike/RBD-ACE2 inhibiting antibody titers $(r>0.86, p<0.001)(76,77)$, with the possibility of anti-nucleocapsid antibodies (signal to cut-off greater than or equal to 5.0) serving as a surrogate for screening of high neutralizing antibody titer plasma (greater than or equal to 160$)$ (78).

\section{Detecting antibodies derived from vaccination versus natural infection}

With the roll-out of SARS-CoV-2 vaccines, the detection and quantification of vaccine-induced antibody by current commercial assays needs to be verified in relation to the detection of natural immunity following infection. A difference in the ability to detect antibodies from both natural infection and vaccination has been seen with other viral infections, including varicella zoster virus (VZV), where commercial assays can readily detect IgG antibodies in people who have had a natural infection but many commercial assays are less robust in detecting vaccineinduced antibodies (79). Multiple studies are currently ongoing to determine what SARS-CoV-2 antibodies are detected with commercial assays, and if there are variances in detection based on the type of vaccine received by an individual. The current lack of serum from vaccinated individuals makes it challenging for a clinical laboratory to incorporate appropriate serology algorithms, particularly as both vaccine and laboratory assay targets are proprietary. Furthermore, with new vaccine candidates emerging, the variability in vaccine type and antigen may limit the ability of current commercial anti-SARS-CoV-2 
serology tests to determine whether a patient has been vaccinated. Moreover, there is no evidence that the presence and titre of anti-SARS-CoV-2 antibodies can be extrapolated to immune status of vaccinated patients.

The role for differentiation of antibodies derived from natural infection versus vaccine-induced antibodies does not have importance for clinical management, and there are currently no Health Canada approved anti-SARS-CoV-2 assays specific for vaccinated populations. In the first four months following vaccination, it is likely that natural versus vaccine-induced antibodies can be differentiated using a combination of anti-nucleocapsid and anti-spike assays. In Canada, for example, where only spike-based vaccines are currently being used, a positive anti-nucleocapsid could indicate natural infection, and a negative anti-nucleocapsid but positive anti-spike could indicate vaccine-induced antibodies. However, this process is not straightforward as negative anti-nucleocapsid but positive anti-spike antibody profiles have been identified in those following natural infection (anti-spike antibodies persist longer than anti-nucleocapsid $(50,80))$. The landscape becomes more complicated after four months or longer because anti-nucleocapsid antibodies are expected to decline among patients who have recovered following natural infection. Therefore, current assays cannot determine whether a patient had positive anti-spike antibodies and negative anti-nucleocapsid antibodies due to a history of infection or a vaccination. From a public health perspective, it is important to understand the overall immunity of a population, and whether immunity is derived from vaccine or natural infection is academic. In jurisdictions using only spike-based vaccines, the use of spike or receptor binding domain assays should be considered as the primary targets for screening to ensure both scenarios are detected in surveillance studies. Conversely, the presence of vaccination-induced antibodies may be problematic for clinical testing; for example, in the diagnosis of MIS-C. As such, clinical serology testing is not recommended for individuals who have received the COVID-19 vaccine, especially if an assay that detects anti-N antibody is not available. Better markers of immune status are needed that are simple, reproducible and robust.

The use of serology in determination of immunity is challenging There are currently no commercially available assays to determine immune status, which can only be evaluated using PRNT assays. In the absence of a universal standard, or a surrogate marker for immunity, the detection of antibodies in serological assays, regardless of the signal strength, cannot determine with confidence whether an individual would be susceptible or immune to a subsequent challenge with SARS-CoV-2. Therefore, the value of an "immunity passport", where individuals with detectable antibody have fewer public health restrictions, is limited and may harm public health efforts aiming to decrease the spread of infection.
Towards the end of 2020, a series of SARS-CoV-2 variants of concern have emerged within different geographic regions of the world, such as the United Kingdom, South Africa and Brazil (81). These variants include specific mutations within the spike protein (K417N, E484K, N501Y) that are shared among all independent variant lineages (82). The most pressing concern with these variants is the increased transmissibility (83) associated with them; but also troubling is the aspect of immune escape, with the potential to evade detection and thus diagnosis. These mutations have been shown to affect neutralization properties depending on whether monoclonal or polyclonal antibodies were tested (84-86). Furthermore, the P.1 variant first found circulating in Manaus, Brazil, was associated with re-infection in immunocompetent individuals (87) which presumably would make it more difficult to interpret results from serology and PRNT assays targeting wild-type virus or viral antigens.

Currently there is no recommendation for pre or post-vaccine immunity screening (88), as there is a lack of correlation between antibody detection and immunity to infection, and little work has been done to understand antibody production in immunocompromised populations. To understand what level of antibody could correlate with immunity from infection, more in-depth studies are needed, including creation of an international standard to allow comparison of antibody levels between different vaccines, assays and laboratories.

\section{Conclusion}

Implementation of SARS-CoV-2 serology in the clinical laboratory is challenging, and laboratory professionals must be aware of the limitations of these assays. There are a number of unknown factors that affect these assays, and guidelines and recommendations for their use in clinical laboratories are ever evolving. Here we present the most up-to-date testing recommendations in Canada, and provide practical guidance for laboratories to choose appropriate serological assays and employ the best testing algorithms for their local populations.

\section{Authors' statement}

CLC - Conceptualized project, original draft, review of manuscript, final editing of manuscript

JNK, VT, JVK, JG, CO, JLR, MD, TH, DRS, AL, LJ, PNL, HW, CT, LRL, MM, JDF, AD - Conceptualized project, original draft, review of manuscript

NE - Review of manuscript, coordination of drafts

All authors have approved the final version sent for publication and are accountable for all aspects of the work.

\section{Competing interests}

None. 


\section{Acknowledgements}

Dr. J Kanji is now with the Division of Infectious Diseases, Department of Medicine, University of Calgary, Calgary, Alberta.

\section{Funding}

None.

\section{References}

1. Van Caeseele P, Bailey D, Forgie SE, Dingle TC, Krajden M; Canadian Public Health Laboratory Network; Canadian Society of Clinical Chemists; Association of Medical Microbiology and Infectious Disease Canada; Canadian Association for Clinical Microbiology and Infectious Diseases; COVID-19 Immunity Task Force. SARS-CoV-2 (COVID-19) serology: implications for clinical practice, laboratory medicine and public health. CMAJ 2020;192(34):E973-9. DOI PubMed

2. Charlton CL, Kanji JN, Johal K, Bailey A, Plitt SS, MacDonald C, Kunst A, Buss E, Burnes LE, Fonseca K, Berenger BM, Schnabl K, Hu J, Stokes W, Zelyas N, Tipples G. Evaluation of Six Commercial Mid- to High-Volume Antibody and Six Point-of-Care Lateral Flow Assays for Detection of SARS-CoV-2 Antibodies. J Clin Microbiol 2020;58(10):e01361-20. DOI PubMed

3. Grzelak L, Temmam S, Planchais C, Demeret C, Tondeur L, Huon C, Guivel-Benhassine F, Staropoli I, Chazal M, Dufloo J, Planas D, Buchrieser J, Rajah MM, Robinot R, Porrot F, Albert M, Chen KY, Crescenzo-Chaigne B, Donati F, Anna F, Souque $\mathrm{P}$, Gransagne M, Bellalou J, Nowakowski M, Backovic M, Bouadma L, Le Fevre L, Le Hingrat $Q$, Descamps D, Pourbaix A, Laouénan C, Ghos J, Yazdanpanah Y, Besombes C, Jolly N, Pellerin-Fernandes $S$, Cheny $O$, Ungeheuer MN, Mellon G, Morel P, Rolland S, Rey FA, Behillil S, Enouf V, Lemaitre $A$, Créach MA, Petres $S$, Escriou N, Charneau P, Fontanet A, Hoen B, Bruel T, Eloit M, Mouquet $H$, Schwartz O, van der Werf S. A comparison of four serological assays for detecting anti-SARS-CoV-2 antibodies in human serum samples from different populations. Sci Transl Med 2020;12(559):eabc3103. DOI PubMed

4. Lee CY, Lin RT, Renia L, Ng LF. Serological Approaches for COVID-19: Epidemiologic Perspective on Surveillance and Control. Front Immunol 2020;11:879. DOI PubMed

5. Centers for Disease Control and Prevention. Information for Healthcare Providers about Multisystem Inflammatory Syndrome in Children (MIS-C). Atlanta (GA): CDC; 2021. https://www.cdc. gov/mis-c/hcp/index.html

6. World Health Organization. Manual for the Laboratory-based Surveillance of Measles, Rubella, and Congenital Rubella Syndrome. Third Edition Edition. WHO: June 2018. https://www.who.int/immunization/monitoring_surveillance/ burden/laboratory/manual/en/
7. Public Health Agency of Canada. Elimination of Measles, Rubella and Congenital Rubella Syndrome in Canada: Documentation and Verification Report. PHAC; 2011. https:// www.canada.ca/en/public-health/services/immunization/ vaccine-preventable-diseases/elimination-measle s-rubella-congenital-rubella-syndrome-canada-documentat ion-verification-report.html

8. Grzelak L, Temmans S, Planchais S, Demeret C, Huon C, Guivel-Benhassine F, Staropoli I, Chazal M, Dufloo J, Planas D, Buchrieser J, Rajah MM, Robinot R, Porrot F, Albert M, Chen K-Y, Crescenzo B, Donati F, Anna F, Souque F, Gransagne M, Bellalou J, Nowakowski M, Backovic M, Bouadma L, Le Fevre L, Le Hingrat Q, Descamps D, Pourbaix A, Yazdanpanah $Y$, Tondeur L, Besombes C, Ungeheuer M-N, Mellon G, Morel P, Rolland S, Rey F, Behillil S, Enouf V, Lemaitre A, Créach M-A, Petres S, Escriou N, Charneau P, Fontanet A, Hoen B, Bruel T, Eloit M, Mouquet H, Schwartz O, van der Werf S. SARS-CoV-2 serological analysis of COVID-19 hospitalized patients, pauci-symptomatic individuals and blood donors. MedRxiv. 2020.04.21.20068858. DOI

9. Long $Q X$, Liu BZ, Deng HJ, Wu GC, Deng $K$, Chen $Y K$, Liao $P$, Qiu JF, Lin Y, Cai XF, Wang DQ, Hu Y, Ren JH, Tang N, Xu YY, Yu LH, Mo Z, Gong F, Zhang XL, Tian WG, Hu L, Zhang XX, Xiang JL, Du HX, Liu HW, Lang CH, Luo XH, Wu SB, Cui XP, Zhou Z, Zhu MM, Wang J, Xue CJ, Li XF, Wang L, Li ZJ, Wang K, Niu CC, Yang QJ, Tang XJ, Zhang Y, Liu XM, Li JJ, Zhang DC, Zhang F, Liu P, Yuan J, Li Q, Hu JL, Chen J, Huang AL. Antibody responses to SARS-CoV-2 in patients with COVID-19. Nat Med 2020;26(6):845-8. DOI PubMed

10. Zhao J, Yuan $Q$, Wang $H$, Liu W, Liao X, Su Y, Wang X, Yuan J, Li T, Li J, Qian S, Hong C, Wang F, Liu Y, Wang Z, He Q, Li Z, He B, Zhang T, Fu Y, Ge S, Liu L, Zhang J, Xia N, Zhang Z. Antibody Responses to SARS-CoV-2 in Patients With Novel Coronavirus Disease 2019. Clin Infect Dis 2020;71(16):2027-34 DOI PubMed

11. Guo L, Ren L, Yang S, Xiao M, Chang D, Yang F, Dela Cruz CS, Wang Y, Wu C, Xiao Y, Zhang L, Han L, Dang S, Xu Y, Yang OW, Xu SY, Zhu HD, Xu YC, Jin Q, Sharma L, Wang L, Wang J. Profiling Early Humoral Response to Diagnose Novel Coronavirus Disease (COVID-19). Clin Infect Dis 2020;71(15):778-85. DOI PubMed

12. Suhandynata RT, Hoffman MA, Kelner MJ, McLawhon RW, Reed SL, Fitzgerald RL. Longitudinal Monitoring of SARS-CoV-2 IgM and IgG Seropositivity to Detect COVID-19. J Appl Lab Med 2020;5(5):908-20. DOl PubMed

13. Seow J, Graham C, Merrick B, Acors S, Pickering S, Steel KJ, Hemmings O, O'Byrne A, Kouphou N, Galao RP, Betancor G, Wilson HD, Signell AW, Winstone H, Kerridge C, Huettner I, Jimenez-Guardeño JM, Lista MJ, Temperton N, Snell LB, Bisnauthsing K, Moore A, Green A, Martinez L, Stokes B, Honey J, Izquierdo-Barras A, Arbane G, Patel A, Tan MK, O'Connell L, O'Hara G, MacMahon E, Douthwaite S, Nebbia G, Batra R, Martinez-Nunez R, Shankar-Hari M, Edgeworth JD, Neil SJ, Malim MH, Doores KJ. Longitudinal observation and decline of neutralizing antibody responses in the three months following SARS-CoV-2 infection in humans. Nat Microbiol 2020;5(12):1598-607. DOl PubMed 
14. Wajnberg A, Amanat F, Firpo A, Altman DR, Bailey MJ Mansour M, McMahon M, Meade P, Mendu DR, Muellers K, Stadlbauer D, Stone K, Strohmeier S, Simon V, Aberg J, Reich DL, Krammer F, Cordon-Cardo C. Robust neutralizing antibodies to SARS-CoV-2 infection persist for months. Science 2020;370(6521):1227-30. DOI PubMed

15. Ripperger TJ, Uhrlaub JL, Watanabe $M$, Wong $R$, Castaneda $Y$, Pizzato HA, Thompson MR, Bradshaw C, Weinkauf CC, Bime C Erickson HL, Knox K, Bixby B, Parthasarathy S, Chaudhary S, Natt B, Cristan E, El Aini T, Rischard F, Campion J, Chopra M, Insel M, Sam A, Knepler JL, Capaldi AP, Spier CM, Dake MD, Edwards T, Kaplan ME, Scott SJ, Hypes C, Mosier J, Harris DT, LaFleur BJ, Sprissler R, Nikolich-Žugich J, Bhattacharya D. Orthogonal SARS-CoV-2 Serological Assays Enable Surveillance of Low-Prevalence Communities and Reveal Durable Humoral Immunity. Immunity 2020;53(5):925-933.e4. DOI PubMed

16. Lau EH, Tsang OT, Hui DS, Kwan MY, Chan WH, Chiu SS, Ko RL, Chan KH, Cheng SM, Perera RA, Cowling BJ, Poon LL, Peiris M. Neutralizing antibody titres in SARS-CoV-2 infections. Nat Commun 2021;12(1):63. DOI PubMed

17. Hartley GE, Edwards ES, Aui PM, Varese N, Stojanovic S, McMahon J, Peleg AY, Boo I, Drummer HE, Hogarth PM, O'Hehir RE, van Zelm MC. Rapid generation of durable B cell memory to SARS-CoV-2 spike and nucleocapsid proteins in COVID-19 and convalescence. Sci Immunol 2020;5(54):eabf8891. DOI PubMed

18. Isho $B$, Abe KT, Zuo M, Jamal AJ, Rathod B, Wang JH, Li Z, Chao G, Rojas OL, Bang YM, Pu A, Christie-Holmes N, Gervais C, Ceccarelli D, Samavarchi-Tehrani P, Guvenc F, Budylowski P, Li A, Paterson A, Yue FY, Marin LM, Caldwell L, Wrana JL, Colwill K, Sicheri F, Mubareka S, Gray-Owen SD, Drews SJ, Siqueira WL, Barrios-Rodiles M, Ostrowski M, Rini JM, Durocher Y, McGeer AJ, Gommerman JL, Gingras AC. Persistence of serum and saliva antibody responses to SARS-CoV-2 spike antigens in COVID-19 patients. Sci Immunol 2020;5(52):eabe5511. PubMed

19. Maine GN, Lao KM, Krishnan SM, Afolayan-Oloye O, Fatemi S, Kumar S, VanHorn L, Hurand A, Sykes E, Sun Q. Longitudinal characterization of the IgM and IgG humoral response in symptomatic COVID-19 patients using the Abbott Architect. J Clin Virol 2020;133:104663. DOI PubMed

20. Sterlin D, Mathian A, Miyara M, Mohr A, Anna F, Claër L, Quentric P, Fadlallah J, Devilliers H, Ghillani P, Gunn C, Hockett R, Mudumba S, Guihot A, Luyt CE, Mayaux J, Beurton A, Fourati S, Bruel T, Schwartz O, Lacorte JM, Yssel H, Parizot C, Dorgham K, Charneau P, Amoura Z, Gorochov G. IgA dominates the early neutralizing antibody response to SARS-CoV-2. Sci Transl Med 2021;13(577):eabd2223. DOI PubMed

21. Gasser $R$, Cloutier $M$, Prévost J, Fink $C$, Ducas É, Ding $S$, Dussault N, Landry P, Tremblay T, Laforce-Lavoie A, Lewin A, Beaudoin-Bussières G, Laumaea A, Medjahed H, Larochelle $C$, Richard J, Dekaban GA, Dikeakos JD, Bazin R, Finzi A. Major role of IgM in the neutralizing activity of convalescent plasma against SARS-CoV-2. Cell Rep 2021;34(9):108790. DOI PubMed

22. Sariol A, Perlman S. Lessons for COVID-19 Immunity from Other Coronavirus Infections. Immunity 2020;53(2):248-63.

DOI PubMed
23. Huang AT, Garcia-Carreras $B$, Hitchings MD, Yang B, Katzelnick LC, Rattigan SM, Borgert BA, Moreno CA, Solomon BD, Trimmer-Smith L, Etienne $\mathrm{V}$, Rodriguez-Barraquer I, Lessler J, Salje H, Burke DS, Wesolowski A, Cummings DA. A systematic review of antibody mediated immunity to coronaviruses: kinetics, correlates of protection, and association with severity. Nat Commun 2020;11(1):4704. DOI PubMed

24. Wu LP, Wang NC, Chang YH, Tian XY, Na DY, Zhang LY, Zheng L, Lan T, Wang LF, Liang GD. Duration of antibody responses after severe acute respiratory syndrome. Emerg Infect Dis 2007;13(10):1562-4. DOI PubMed

25. Tang F, Quan Y, Xin ZT, Wrammert J, Ma MJ, Lv H, Wang TB, Yang H, Richardus JH, Liu W, Cao WC. Lack of peripheral memory B cell responses in recovered patients with severe acute respiratory syndrome: a six-year follow-up study. J Immunol 2011;186(12):7264-8. DOl PubMed

26. Payne DC, Iblan I, Rha B, Alqasrawi S, Haddadin A, Al Nsour M, Alsanouri T, Ali SS, Harcourt J, Miao C, Tamin A, Gerber SI, Haynes LM, Al Abdallat MM. Persistence of Antibodies against Middle East Respiratory Syndrome Coronavirus. Emerg Infect Dis 2016;22(10):1824-6. DOI PubMed

27. Zhao J, Alshukairi AN, Baharoon SA, Ahmed WA, Bokhari AA, Nehdi AM, Layqah LA, Alghamdi MG, Al Gethamy MM, Dada AM, Khalid I, Boujelal M, Al Johani SM, Vogel L, Subbarao K, Mangalam A, Wu C, Ten Eyck P, Perlman $\mathrm{S}$, Zhao J. Recovery from the Middle East respiratory syndrome is associated with antibody and T-cell responses. Sci Immunol 2017;2(14):eaan5393. DOI PubMed

28. Kowitdamrong $\mathrm{E}$, Puthanakit $\mathrm{T}$, Jantarabenjakul $\mathrm{W}$, Prompetchara E, Suchartlikitwong P, Putcharoen O, Hirankarn N, Putcharoen O, Hirankarn N. Antibody responses to SARS-CoV-2 in patients with differing severities of coronavirus disease 2019. PLoS One 2020;15(10):e0240502. DOI PubMed

29. Marklund $E$, Leach $S$, Axelsson $H$, Nyström $K$, Norder $H$, Bemark M, Angeletti D, Lundgren A, Nilsson S, Andersson LM, Yilmaz A, Lindh M, Liljeqvist JÅ, Gisslén M. Serum-IgG responses to SARS-CoV-2 after mild and severe COVID-19 infection and analysis of IgG non-responders. PLoS One 2020;15(10):e0241104. DOl PubMed

30. Kalkan Yazıcı M, Koç MM, Çetin NS, Karaaslan E, Okay G, Durdu B, Sümbül B, Doymaz MZ. Discordance between Serum Neutralizing Antibody Titers and the Recovery from COVID-19. J Immunol 2020;205(10):2719-25. DOI PubMed

31. Shen $L$, Wang $C$, Zhao J, Tang $X$, Shen $Y$, Lu M, Ding Z, Huang $C$, Zhang J, Li S, Lan J, Wong G, Zhu Y. Delayed specific IgM antibody responses observed among COVID-19 patients with severe progression. Emerg Microbes Infect 2020;9(1):1096-101. DOI PubMed

32. Jiang $C$, Wang $Y$, Hu M, Wen L, Wen $C$, Wang $Y$, Zhu W, Tai S, Jiang Z, Xiao K, Faria NR, De Clercq E, Xu J, Li G. Antibody seroconversion in asymptomatic and symptomatic patients infected with severe acute respiratory syndrome coronavirus 2 (SARS-CoV-2). Clin Transl Immunology 2020;9(9):e1182. DOI PubMed 
33. Ibarrondo FJ, Fulcher JA, Goodman-Meza D, Elliott J, Hofmann C, Hausner MA, Ferbas KG, Tobin NH, Aldrovandi GM, Yang OO. Rapid Decay of Anti-SARS-CoV-2 Antibodies in Persons with Mild Covid-19. N Engl J Med 2020;383(11):1085-7. DOI PubMed

34. Choe PG, Kang CK, Suh HJ, Jung J, Song KH, Bang JH, Kim ES, Kim HB, Park SW, Kim NJ, Park WB, Oh MD. Waning Antibody Responses in Asymptomatic and Symptomatic SARS-CoV-2 Infection. Emerg Infect Dis 2021;27(1):327-9. DOI PubMed

35. Long QX, Tang XJ, Shi QL, Li Q, Deng HJ, Yuan J, Hu JL, Xu W, Zhang Y, Lv FJ, Su K, Zhang F, Gong J, Wu B, Liu XM, Li JJ, Qiu JF, Chen J, Huang AL. Clinical and immunological assessment of asymptomatic SARS-CoV-2 infections. Nat Med 2020;26(8):1200-4. DOI PubMed

36. Choe PG, Kang CK, Suh HJ, Jung J, Kang E, Lee SY, Song KH, Kim HB, Kim NJ, Park WB, Kim ES, Oh MD. Antibody Responses to SARS-CoV-2 at 8 Weeks Postinfection in Asymptomatic Patients. Emerg Infect Dis 2020;26(10):2484-7. DOI PubMed

37. Tillett RL, Sevinsky JR, Hartley PD, Kerwin H, Crawford N, Gorzalski A, Laverdure C, Verma SC, Rossetto CC, Jackson D, Farrell MJ, Van Hooser S, Pandori M. Genomic evidence for reinfection with SARS-CoV-2: a case study. Lancet Infect Dis 2021;21(1):52-8. DOI PubMed

38. To KK, Hung IF, Ip JD, Chu AW, Chan WM, Tam AR, Fong $\mathrm{CH}$, Yuan S, Tsoi HW, Ng AC, Lee LL, Wan P, Tso E, To WK, Tsang D, Chan KH, Huang JD, Kok KH, Cheng VC, Yuen KY. COVID-19 re-infection by a phylogenetically distinct SARS-coronavirus-2 strain confirmed by whole genome sequencing. Clin Infect Dis 2020 Aug;ciaa1275. (Online head of print). DOI PubMed

39. Van Elslande J, Vermeersch P, Vandervoort K, Wawina-Bokalanga T, Vanmechelen B, Wollants E, Laenen L, André E, Van Ranst M, Lagrou K, Maes P. Symptomatic SARS-CoV-2 reinfection by a phylogenetically distinct strain. Clin Infect Dis 2020; ciaa1330. (Online head of print). DOI PubMed

40. Prado-Vivar B, Becerra-Wong $M$, Guadalupe JJ, Márquez $S$, Gutierrez B, Rojas-Silva P, Grunauer M, Treuba G, Barragan V, Cardenas P. A case of SARS-CoV-2 reinfection in Ecuador. Lancet Infect Dis 2020. (Online head of print). DOI

41. Weisberg SP, Connors TJ, Zhu Y, Baldwin MR, Lin WH, Wontakal S, Szabo PA, Wells SB, Dogra P, Gray J, Idzikowski E, Stelitano D, Bovier FT, Davis-Porada J, Matsumoto R, Poon MM, Chait M, Mathieu C, Horvat B, Decimo D, Hudson KE, Zotti FD, Bitan ZC, La Carpia F, Ferrara SA, Mace E, Milner J, Moscona A, Hod E, Porotto M, Farber DL. Distinct antibody responses to SARS-CoV-2 in children and adults across the COVID-19 clinical spectrum. Nat Immunol 2021;22(1):25-31. DOI PubMed

42. National Association of Testing Authorities. Australia (NATA). General Accreditation Guidance - Validation and verification of quantitative and qualitative test methods. Australia: NATA; 2018. https://www.nata.com.au/phocadownload/ gen-accreditation-guidance/Validation-and-Verification-o f-Quantitative-and-Qualitative-Test-Methods.pdf

43. Farnsworth CW, Anderson NW. SARS-CoV-2 Serology: Much Hype, Little Data. Clin Chem 2020;66(7):875-7. DOI PubMed

44. Kohmer N, Westhaus S, Rühl C, Ciesek S, Rabenau HF. Brief clinical evaluation of six high-throughput SARS-CoV-2 IgG antibody assays. J Clin Virol 2020;129:104480. DOI PubMed
45. Manthei DM, Whalen JF, Schroeder LF, Sinay AM, Li SH, Valdez R, Giacherio DA, Gherasim C. Differences in Performance Characteristics Among Four High-Throughput Assays for the Detection of Antibodies Against SARS-CoV-2 Using a Common Set of Patient Samples. Am J Clin Pathol 2021;155(2):267-79. DOI PubMed

46. Merrill AE, Jackson JB, Ehlers A, Voss D, Krasowski MD. Head-to-Head Comparison of Two SARS-CoV-2 Serology Assays. J Appl Lab Med 2020;5(6):1351-7. DOI PubMed

47. Perkmann T, Perkmann-Nagele N, Breyer MK, Breyer-Kohansal R, Burghuber OC, Hartl S, Aletaha D, Sieghart D, Quehenberger P, Marculescu R, Mucher P, Strassl R, Wagner OF, Binder CJ, Haslacher H. Side-by-Side Comparison of Three Fully Automated SARS-CoV-2 Antibody Assays with a Focus on Specificity. Clin Chem 2020;66(11):1405-13. DOI PubMed

48. Prince HE, Givens TS, Lapé-Nixon M, Clarke NJ, Schwab DA, Batterman HJ, Jones RS, Meyer WA 3rd, Kapoor H, Rowland CM, Haji-Sheikhi F, Marlowe EM. Detection of SARS-CoV-2 lgG Targeting Nucleocapsid or Spike Protein by Four High-Throughput Immunoassays Authorized for Emergency Use. J Clin Microbiol 2020;58(11):e01742-20. DOI PubMed

49. Pflüger LS, Bannasch JH, Brehm TT, Pfefferle $S$, Hoffmann A, Nörz D, van der Meirschen M, Kluge S, Haddad M, Pischke S, Hiller J, Addo MM, Lohse AW, Schulze Zur Wiesch J, Peine S, Aepfelbacher M, Lütgehetmann M. Clinical evaluation of five different automated SARS-CoV-2 serology assays in a cohort of hospitalized COVID-19 patients. J Clin Virol 2020;130:104549. DOI PubMed

50. Ripperger TJ, Uhrlaub JL, Watanabe M, Wong R, Castaneda $Y$, Pizzato HA, Thompson MR, Bradshaw C, Weinkauf CC, Bime C, Erickson HL, Knox K, Bixby B, Parthasarathy S, Chaudhary S, Natt B, Cristan E, T El Aini, Rischard F, Campion J, Chopra M, Insel M, Sam A, Knepler JL, Capaldi AP, Spier CM, Dake MD, Edwards T, Kaplan ME, Scott SJ, Hypes C, Mosier J, Harris DT, LaFleur BJ, Sprissler R, Nikolich-Ž J, Bhattacharya D. Detection, prevalence, and duration of humoral responses to SARS-CoV-2 under conditions of limited population exposure. medRxiv. 2020. (Online ahead of print). DOI

51. Xu G, Emanuel AJ, Nadig S, Mehrotra S, Caddell BA, Curry SR,Nolte FS, Babic N. Evaluation of Orthogonal Testing Algorithm for Detection of SARS-CoV-2 lgG Antibodies. Clin Chem. 2020;66(12)1531-7. DOI

52. Centers for Disease Control and Prevention. Interim Guidelines for COVID-19 Antibody Testing. Atlanta (GA); CDC; (updated 2021-03). https://www.cdc.gov/coronavirus/2019-ncov/lab/ resources/antibody-tests-guidelines.html

53. Stadlbauer D, Amanat F, Chromikova V, Jiang K, Strohmeier S, Arunkumar GA, Tan J, Bhavsar D, Capuano C, Kirkpatrick E, Meade P, Brito RN, Teo C, McMahon M, Simon V, Krammer F. SARS-CoV-2 Seroconversion in Humans: A Detailed Protocol for a Serological Assay, Antigen Production, and Test Setup. Curr Protoc Microbiol 2020;57(1):e100. DOI PubMed

54. Coste AT, Jaton K, Papadimitriou-Olivgeris M, Greub G, Croxatto A. Comparison of SARS-CoV-2 serological tests with different antigen targets. J Clin Virol 2021;134:104690. DOI PubMed 
55. DomBourian MG. Annen K, Huey L, Andersen G, Merkel PA, Jung S, Dominguez SR, Knight V. Analysis of COVID-19 convalescent plasma for SARS-CoV-2 IgG using two commercial immunoassays. J Immunol Methods 2020;486:112837. DOI

56. Turbett SE, Anahtar M, Dighe AS, Garcia Beltran W, Miller T, Scott H, Durbin SM, Bharadwaj M, Thomas J, Gogakos TS, Astudillo M, Lennerz J, Rosenberg ES, Branda JA. Evaluation of Three Commercial SARS-CoV-2 Serologic Assays and Their Performance in Two-Test Algorithms. J Clin Microbiol 2020;59(1):e01892-20. DOI PubMed

57. Hoste AC, Venteo A, Fresco-Taboada A, Tapia I, Monedero A López L, Jebbink MF, Pérez-Ramírez E, Jimenez-Clavero MA, Almonacid $M$, Muñoz $P$, Guinea J, Vela $C$, van der Hoek $L$, Rueda P, Sastre P. Two serological approaches for detection of antibodies to SARS-CoV-2 in different scenarios: a screening tool and a point-of-care test. Diagn Microbiol Infect Dis 2020;98(4):115167. DOI PubMed

58. Pallett SJ, Jones R, Pallett MA, Rayment M, Mughal N, Davies GW, Moore LS. Characterising differential antibody response is integral to future SARS-CoV-2 serostudies. J Infect 2020;81(6):e28-30. DOI PubMed

59. Perkmann T, Perkmann-Nagele N, Oszvar-Kozma M, Koller T, Breyer M-K, Breyer-Kohansal R, Burghuber OC, Harti S, Aletaha D, Sieghart D, Quehenberger P, Marculescu R, Mucher P, Radakovics A, Strassl R, Leitner G, Wagner OF, Binder CJ, Haslacher $\mathrm{H}$. Increasing both specificity and sensitivity of SARS-CoV-2 antibody tests by using an adaptive orthogonal testing approach. medRxiv. 2020.11.05.20226449. (Online ahead of print). DOI

60. Ng DL, Goldgof GM, Shy BR, Levine AG, Balcerek J, Bapat SP, Prostko J, Rodgers M, Coller K, Pearce S, Franz S, Du L, Stone M, Pillai SK, Sotomayor-Gonzalez A, Servellita V, Martin CS, Granados A, Glasner DR, Han LM, Truong K, Akagi N, Nguyen DN, Neumann NM, Qazi D, Hsu E, Gu W, Santos YA, Custer B, Green V, Williamson P, Hills NK, Lu CM, Whitman JD, Stramer SL, Wang C, Reyes K, Hakim JM, Sujishi K, Alazzeh F, Pham L, Thornborrow E, Oon CY, Miller S, Kurtz T, Simmons G, Hackett J Jr, Busch MP, Chiu CY. SARS-CoV-2 seroprevalence and neutralizing activity in donor and patient blood. Nat Commun 2020;11(1):4698. DOI PubMed

61. Kaufer AM, Theis T, Lau KA, Gray JL, Rawlinson WD. Laboratory biosafety measures involving SARS-CoV-2 and the classification as a Risk Group 3 biological agent. Pathology 2020;52(7):790-5. DOl PubMed

62. Lee WT, Girardin RC, Dupuis AP, Kulas KE, Payne AF, Wong SJ, Arinsburg S, Nguyen FT, Mendu DR, Firpo-Betancourt A, Jhang J, Wajnberg A, Krammer F, Cordon-Cardo C, Amler S, Montecalvo M, Hutton B, Taylor J, McDonough KA. Neutralizing Antibody Responses in COVID-19 Convalescent Sera. J Infect Dis 2021;223(1):47-55. DOI PubMed

63. Mendoza EJ, Manguiat K, Wood H, Drebot M. Two Detailed Plaque Assay Protocols for the Quantification of Infectious SARS-CoV-2. Curr Protoc Microbiol. 2020;57(1):ecpmc105. DOI

64. Crawford KH, Eguia R, Dingens AS, Loes AN, Malone KD, Wolf CR, Chu HY, Tortorici MA, Veesler D, Murphy M, Pettie D, King NP, Balazs AB, Bloom JD. Protocol and Reagents for Pseudotyping Lentiviral Particles with SARS-CoV-2 Spike Protein for Neutralization Assays. Viruses 2020;12(5):513. DOI PubMed
65. Tan CW, Chia WN, Qin X, Liu P, Chen MI, Tiu C, Hu Z, Chen VC, Young BE, Sia WR, Tan YJ, Foo R, Yi Y, Lye DC, Anderson DE, Wang LF. A SARS-CoV-2 surrogate virus neutralization test based on antibody-mediated blockage of ACE2-spike protein-protein interaction. Nat Biotechnol 2020;38(9):1073-8. DOI PubMed

66. Muruato $A E$, Fontes-Garfias $C R$, Ren $P$, Garcia-Blanco MA, Menachery VD, Xie X, Shi PY. A high-throughput neutralizing antibody assay for COVID-19 diagnosis and vaccine evaluation. Nat Commun 2020;11(1):4059. DOI PubMed

67. Abe KT, Li Z, Samson R, Samavarchi-Tehrani P, Valcourt EJ, Wood H, Budylowski P, Dupuis AP $2^{\text {nd }}$, Girardin RC, Rathod B, Wang JH, Barrios-Rodiles M, Colwill K, McGeer AJ, Mubareka S, Gommerman JL, Durocher Y, Ostrowski M, McDonough KA, Drebot MA, Drews SJ, Rini JM, Gingras AC. A simple protein-based surrogate neutralization assay for SARS-CoV-2. JCI Insight 2020;5(19):e142362. DOI PubMed

68. Meyer B, Reimerink J, Torriani G, Brouwer F, Godeke GJ, Yerly S, Hoogerwerf M, Vuilleumier N, Kaiser L, Eckerle I, Reusken $\mathrm{C}$. Validation and clinical evaluation of a SARS-CoV-2 surrogate virus neutralisation test (sVNT). Emerg Microbes Infect 2020;9(1):2394-403. DOI PubMed

69. Valcourt EJ, Manguiat K, Robinson A, Chen JC, Dimitrova K, Philipson C, Lamoureux L, McLachlan E, Schiffman Z, Drebot MA, Wood H. Evaluation of a commercially-available surrogate virus neutralization test for severe acute respiratory syndrome coronavirus-2 (SARS-CoV-2). Diagn Microbiol Infect Dis 2021;99(4):115294. DOI PubMed

70. Taylor SC, Hurst B, Charlton CL, Bailey A, Kanji JN, McCarthy MK, Morrison TE, Huey L, Annen K, DomBourian MG, Knight V. A New SARS CoV-2 Dual Purpose Serology Test: Highly Accurate Infection Tracing and Neutralizing Antibody Response Detection. J Clin Microbiol. 2021;JCM.02438-20. DOI

71. Riepler L, Rössler A, Falch A, Volland A, Borena W, von Laer D, Kimpel J. Comparison of Four SARS-CoV-2 Neutralization Assays. Vaccines (Basel) 2020;9(1):13. DOI PubMed

72. Perera RA, Mok CK, Tsang OT, Lv H, Ko RL, Wu NC, Yuan M, Leung WS, Chan JM, Chik TS, Choi CY, Leung K, Chan KH, Chan KC, Li KC, Wu JT, Wilson IA, Monto AS, Poon LL, Peiris M. Serological assays for severe acute respiratory syndrome coronavirus 2 (SARS-CoV-2), March 2020. Euro Surveill 2020;25(16):2000421. DOI PubMed

73. Bonelli F, Sarasini A, Zierold C, Calleri M, Bonetti A, Vismara C, Blocki FA, Pallavicini L, Chinali A, Campisi D, Percivalle E, DiNapoli AP, Perno CF, Baldanti F. Clinical and Analytical Performance of an Automated Serological Test That Identifies S1/S2-Neutralizing lgG in COVID-19 Patients Semiquantitatively. J Clin Microbiol 2020;58(9):e01224-20. DOI PubMed

74. Valdivia A, Torres I, Latorre V, Francés-Gómez C Albert E, Gozalbo-Rovira R, Alcaraz MJ, Buesa J, Rodríguez-Díaz J, Geller R, Navarro D. Inference of SARS-CoV-2 spike-binding neutralizing antibody titers in sera from hospitalized COVID-19 patients by using commercial enzyme and chemiluminescent immunoassays. Eur J Clin Microbiol Infect Dis 2021;40(3):485-94. DOI PubMed 
75. Patel EU, Bloch EM, Clarke W, Hsieh YH, Boon D, Eby Y, Fernandez RE, Baker OR, Keruly M, Kirby CS, Klock E, Littlefield K, Miller J, Schmidt HA, Sullivan $P$, Piwowar-Manning E, Shrestha R, Redd AD, Rothman RE, Sullivan D, Shoham S, Casadevall A, Quinn TC, Pekosz A Tobian AA, Laeyendecker O. Comparative Performance of Five Commercially Available Serologic Assays To Detect Antibodies to SARS-CoV-2 and Identify Individuals with High Neutralizing Titers. J Clin Microbiol 2021;59(2):e02257-20. DOI PubMed

76. L'Huillier AG, Meyer B, Andrey DO, Arm-Vernez I, Baggio S, Didierlaurent A, Eberhardt CS, Eckerle I, Grasset-Salomon C, Huttner A, Posfay-Barbe KM, Royo IS, Pralong JA, Vuilleumier N, Yerly S, Siegrist CA, Kaiser L. Geneva Centre for Emerging Viral Diseases. Antibody persistence in the first 6 months following SARS-CoV-2 infection among hospital workers: a prospective longitudinal study. Clin Microbiol Infect. 2021;S1198-743X(21)00031-8. DOI

77. Iyer AS, Jones FK, Nodoushani A, Kelly M, Becker M, Slater D, Mills R, Teng E, Kamruzzaman M, Garcia-Beltran WF, Astudillo M, Yang D, Miller TE, Oliver E, Fischinger S, Atyeo C, lafrate AJ, Calderwood SB, Lauer SA, Yu J, Li Z, Feldman J, Hauser BM, Caradonna TM, Branda JA, Turbett SE, LaRocque RC, Mellon G, Barouch DH, Schmidt AG, Azman AS, Alter G, Ryan ET, Harris JB, Charles RC. Persistence and decay of human antibody responses to the receptor binding domain of SARS-CoV-2 spike protein in COVID-19 patients. Sci Immunol 2020;5(52):eabe0367. DOI PubMed

78. Wendel S, Fontão-Wendel R, Fachini R, Candelaria G, Scuracchio P, Achkar R, Brito M, Reis LF, Camargo A, Amano M, Machado R, Araujo D, Soares C, Durigon E. A longitudinal study of convalescent plasma (CCP) donors and correlation of $A B O$ group, initial neutralizing antibodies ( $n A b)$, and body mass index (BMI) with nAb and anti-nucleocapsid (NP) SARS-CoV-2 antibody kinetics: proposals for better quality of CCP collections. Transfusion 2021. (Online head of print). DOI PubMed

79. National Advisory Committee on Immunization (NACl). Varicella (chickenpox) vaccine: Canadian Immunization Guide. Ottawa (ON): NACl; 2018. https://www.canada. $\mathrm{ca} / \mathrm{en} /$ public-health/services/publications/healthy-living/ canadian-immunization-guide-part-4-active-vaccines/page24-varicella-chickenpox-vaccine.html

80. Fenwick C, Croxatto A, Coste AT, Pojer F, André C, Pellaton C, Farina A, Campos J, Hacker D, Lau K, Bosch BJ, Gonseth Nussle S, Bochud M, D'Acremont V, Trono D, Greub G, Pantaleo G. Changes in SARS-CoV-2 Spike versus Nucleoprotein Antibody Responses Impact the Estimates of Infections in Population-Based Seroprevalence Studies. J Virol 2021;95(3):e01828-20. DOI PubMed

81. Kupferschmidt K. New coronavirus variants could cause more reinfections, require updated vaccines. Science 2021. https://www.sciencemag.org/news/2021/01/ new-coronavirus-variants-could-cause-more-reinfections-req uire-updated-vaccines
82. European Centre for Disease Prevention and Control. Risk Assessment: Risk related to spread of new SARS-CoV-2 variants of concern in the EU/EEA. ECDC; 2020.

https://www.ecdc.europa.eu/en/publications-data/covid-19-riskassessment-spread-new-sars-cov-2-variants-eueea

83. World Health Organization. SARS-CoV-2 Variants. Geneva (Switzerland): WHO; 2020. https://www.who.int/csr/don/31december-2020-sars-cov2-variants/en/

84. Greaney AJ, Loes AN, Crawford KH, Starr TN, Malone KD, Chu HY, Bloom JD. Comprehensive mapping of mutations in the SARS-CoV-2 receptor-binding domain that affect recognition by polyclonal human plasma antibodies. Cell Host Microbe 2021;29(3):463-476.e6. DOI PubMed

85. Wibmer CK, Ayres F, Hermanus T, Madzivhandila M, Kgagudi P, Lambson BE, de Oliveira T, Vermeulen M, van der Berg K, Rossouw T, Boswell M, Ueckermann V, Meiring $S$, von Gottberg A, Cohen C, Morris L, Bhiman JN, Moore PL. SARS-CoV-2 501Y.V2 escapes neutralization by South African COVID-19 donor plasma. bioRxiv. 2021.01.18.427166. (Online head of print). DOI

86. Wang Z, Schmidt F, Weisblum Y, Muecksch F, Barnes $C O$ Finkin S, Schaefer-Babajew D, Cipolla M, Gaebler C, Lieberman JA, Oliveira TY, Yang Z, Abernathy ME, Huey-Tubman KE, Hurley A, Turroja M, West KA, Gordon K, Millard KG, Ramos V, Da Silva J, Xu J, Colbert RA, Patel R, Dizon J, Unson-O'Brien C, Shimeliovich I, Gazumyan A, Caskey M, Bjorkman PJ, Casellas R, Hatziioannou T, Bieniasz PD Nussenzweig MC. mRNA vaccine-elicited antibodies to SARS-CoV-2 and circulating variants. Nature. 2021;592:616-22. (Online ahead of print). DOI

87. Naveca F, da Costa C, Nascimento V, Souza V, Corado A, Nascimento F, Costa A, Duarte D, Silva G, Mejia M, Pessoa K, Goncalves L, Brandao MJ, Jesus M, Pinto R, Silva M, Mattros T, Abdalla L, Santos JH, Costa-Filho R, Wallau GL, Siqueira MM, Delatorre E, Graf T, Bello G, Resende PC. SARS-CoV-2 reinfection by the new Variant of Concern (VOC) P.1 in Amazonas, Brazil. Virological. Jan 17, 2021. https://virological. org/t/sars-cov-2-reinfection-by-the-new-variant-of-concern-vocp-1-in-amazonas-brazil/596

88. National Advisory Committee on Immunization (NACl). Recommendations on the use of COVID-19 vaccines. Ottawa (ON): NACl; 2021. https://www.canada.ca/en/public-health/ services/immunization/national-advisory-committee-o n-immunization-naci/recommendations-use-covid-19-vaccines. html 